\title{
Activation of $\sigma$-Receptors Induces Binge-like Drinking in Sardinian Alcohol-Preferring Rats
}

\author{
Valentina Sabino*, $1,2,6$, Pietro Cottone ${ }^{1,2,6}$, Angelo Blasio ${ }^{2,4}$, Malliga R lyer ${ }^{3}$, Luca Steardo ${ }^{4}$, Kenner C Rice ${ }^{3}$, \\ Bruno Conti ${ }^{5}$, George F Koob' and Eric P Zorrilla' \\ 'Committee on the Neurobiology of Addictive Disorders, The Scripps Research Institute, La Jolla, CA, USA; ${ }^{2}$ Laboratory of Addictive Disorders, \\ Department of Pharmacology and Experimental Therapeutics, Boston University School of Medicine, Boston, MA, USA; ${ }^{3}$ Chemical Biology \\ Research Branch, National Institute on Drug Abuse and National Institute on Alcohol Abuse and Alcoholism, Bethesda, MD, USA; ${ }^{4}$ Department \\ of Human Physiology and Pharmacology, University of Rome La Sapienza, Rome, Italy; ${ }^{5}$ Molecular and Integrative Neurosciences Department, \\ The Scripps Research Institute, La Jolla, CA, USA
}

Sigma $(\sigma)$ receptors have been implicated in the behavioral and motivational effects of alcohol and psychostimulants. Sigma receptor antagonists reduce the reinforcing effects of alcohol and excessive alcohol intake in both genetic (alcohol-preferring rats) and environmental (chronic alcohol-induced) models of alcoholism. The present study tested the hypothesis that pharmacological activation of $\sigma$-receptors facilitates ethanol reinforcement and induces excessive, binge-like ethanol intake. The effects of repeated subcutaneous treatment with the selective $\sigma$-receptor agonist I,3-di-(2-tolyl)guanidine (DTG; $15 \mathrm{mg} / \mathrm{kg}$, twice a day for 7 days) on operant ethanol $(10 \%)$ self-administration were studied in Sardinian alcohol-preferring (sP) rats. To confirm that the effect of DTG was mediated by $\sigma$-receptors, the effects of pretreatment with the selective $\sigma$-receptor antagonist BD- 1063 (7 mg/kg, subcutaneously) were determined. To assess the specificity of action, the effects of DTG on the self-administration of equally reinforcing solutions of saccharin or sucrose were also determined. Finally, gene expression of opioid receptors in brain areas implicated in ethanol reinforcement was analyzed in ethanol-naive SP rats treated acutely or repeatedly with DTG, because of the well-established role of the opioid system in alcohol reinforcement and addiction. Repeatedly administered DTG progressively and dramatically increased ethanol self-administration in sP rats and increased blood alcohol levels, which reached mean values close to $100 \mathrm{mg} \%$ in I h drinking sessions. Repeated DTG treatment also increased the rats' motivation to work for alcohol under a progressive-ratio schedule of reinforcement. BD- 1063 prevented the effects of DTG, confirming that $\sigma$-receptors mediate the effects of DTG. Repeated DTG treatment also increased the self-administration of the non-drug reinforcers saccharin and sucrose. Naive sP rats repeatedly treated with DTG showed increased mRNA expression of $\mu$ - and $\delta$-opioid receptors in the ventral tegmental area. These results suggest a key facilitatory role for $\sigma$-receptors in the reinforcing effects of alcohol and identify a potential mechanism that contributes to binge-like and excessive drinking.

Neuropsychopharmacology (201 I) 36, I207-1218; doi:I0.1038/npp.201 I.5; published online 23 February 201 I

Keywords: alcohol \& alcoholism; addiction \& substance abuse; alcohol OR ethanol; dependence; self-administration; binge-like OR binge

\section{INTRODUCTION}

Sigma $(\sigma)$ receptors have long been hypothesized to be a novel neuropharmacological target with psychotherapeutic

\footnotetext{
*Correspondence: Dr $\vee$ Sabino, Laboratory of Addictive Disorders, Boston University School of Medicine, 72 E Concord Street, R612, Boston, MA 021 I 8, USA. Tel: 617638 4327; Fax: 617638 4329,

E-mail: vsabino@bu.edu or Dr Eric Zorrilla, Committee on the Neurobiology of Addictive Disorders, SP30-2400, The Scripps Research Institute, 10550 N Torrey Pines Road, La Jolla, CA 92037, USA. Tel: 858784 7470, Fax: 8587847405 ,

E-mail: ezorrilla@scripps.edu

${ }^{6}$ These authors contributed equally to this work Received 18 August 2010; revised 26 December 2010; accepted 5 January 2011
}

potential. They were originally categorized as members of the opioid receptor family (Martin et al, 1976) and highaffinity phencyclidine binding sites (Quirion et al, 1992). However, more recent data demonstrate that $\sigma$-receptors are unique binding sites that differ from other known mammalian proteins (Gundlach et al, 1986; Walker et al, 1990). Sigma receptors were recently identified as novel ligand-operated molecular chaperones expressed predominantly at the endoplasmic reticulum subdomain that apposes mitochondria (ie, the mitochondria associated endoplasmic reticulum membrane; Hayashi and $\mathrm{Su}$, 2007). Sigma receptors are highly dynamic under certain conditions in which they are translocated from the mitochondria associated endoplasmic reticulum membrane to loci close to the plasma membranes (eg, plasmalemma; 
Hayashi and Su, 2003, 2007). Through this mechanism, $\sigma$-receptors may regulate cellular events at the plasma membranes, including calcium flux, neurotransmitter release, neurotrophic factor signaling, and the opening of voltage-gated ion channels (Aydar et al, 2002; Hayashi and $\mathrm{Su}, 2008$; Herrera et al, 2008).

Several structurally unrelated molecules have been proposed as endogenous $\sigma$-receptor ligands, including neurosteroids (eg, dehydroepiandrosterone and progesterone), neuropeptide $\mathrm{Y}$, calcitonin gene-related peptide, and more recently the trace amine $N, N$-dimethyltryptamine (Fontanilla et al, 2009; Maurice et al, 1999; Su et al, 1993). Two different $\sigma$-receptor subtypes are currently known, $\sigma-1$ and $\sigma-2$, which differ in their binding profiles and molecular sizes. Only the $\sigma-1$ subtype has been cloned (Hanner et al, 1996; Hellewell and Bowen, 1990; Moebius et al, 1993).

The activation of $\sigma$-receptors has been shown to result in the modulation of multiple neurotransmitter systems, such as glutamatergic, cholinergic, noradrenergic, and dopaminergic (Ault et al, 1998; Ault and Werling, 1999; Gronier and Debonnel, 1999; Skuza and Kolasiewicz, 2001; Su and Hayashi, 2003; Weatherspoon et al, 1996). In the rat brain, $\sigma$-receptors are widely expressed in the limbic system and brainstem, with the highest levels seen in the olfactory bulb, hypothalamus, and hippocampus. The ventral and dorsal striatum, amygdala, ventral tegmental area (VTA), and locus coeruleus also show moderate to intense $\sigma$ receptor immunoreactivity (Alonso et al, 2000; Bouchard and Quirion, 1997).

A growing body of evidence shows that $\sigma$-receptor antagonists block several effects induced by psychostimulants and ethanol, suggesting that the activation of $\sigma$-receptors contributes to drug-induced motivational effects. Sigma receptor antagonists block psychostimulantinduced locomotor activation, psychostimulant-induced conditioned place preference (CPP), and cue-induced reinstatement of cocaine-seeking behavior, although they do not appear to decrease cocaine self-administration (Hiranita et al, 2009; Martin-Fardon et al, 2007; Matsumoto et al, 2003; Maurice et al, 2002; Nguyen et al, 2005; Takahashi et al, 2000). Sigma receptor antagonists attenuate ethanol-induced locomotor activity and block the acquisition of ethanol-induced conditioned place preference (Maurice et al, 2003). Our laboratory has shown that $\sigma$-receptor antagonists reduce operant ethanol selfadministration and home-cage drinking in conditions of high baseline drinking (ethanol-dependent and genetically selected alcohol-preferring rats), decrease the motivation to work for ethanol in a progressive-ratio schedule of reinforcement, and attenuate the increased drinking associated with the alcohol deprivation effect (Sabino et al, 2009a, b).

Much research has studied the ability of $\sigma$-receptor antagonists to attenuate the rewarding and reinforcing effects of drugs of abuse, but very little is known about the behavioral effects of $\sigma$-receptor agonists in relation to drugs of abuse and alcohol. Sigma receptor agonists do not substitute for cocaine in subjects trained to discriminate cocaine from saline injections (Ukai et al, 1997). Sigma receptor agonists, such as 1,3-di-(2-tolyl) guanidine (DTG), PRE-084, igmesine, and some neuro- steroids that act as $\sigma$-receptor agonists, have been shown to be ineffective in inducing CPP when given alone, but to facilitate the CPP induced by cocaine (Maurice and Romieu, 2004; Romieu et al, 2000; Romieu et al, 2002). The $\sigma$-receptor agonists dehydroepiandrosterone and igmesine also can reactivate cocaine-CPP (Romieu et al, 2004). Finally, $\sigma$-receptor agonists shift the dose-response curve for cocaine self-administration to the left and are actively self-administered by rats with a history of cocaine selfadministration (Hiranita et al, 2010; Hiranita et al, 2009). In a study designed to investigate the effects of $\sigma$-receptor agonists on the rewarding properties of alcohol, Maurice et al (2003) showed that the $\sigma$-receptor agonist PRE-084 dose-dependently enhanced the CPP induced by a low dose of ethanol.

Therefore, the purpose of the present study was to test the hypothesis that pharmacological activation of $\sigma$-receptors facilitates the reinforcing effects of ethanol. Specifically, $\sigma$-receptor agonists were expected to potentiate the reinforcing action of alcohol and result in excessive alcohol drinking. To test this hypothesis, we examined the effects of repeated treatment with the selective $\sigma$-receptor agonist DTG on operant ethanol self-administration in Sardinian alcohol-preferring (sP) rats. To confirm that the effect of DTG was mediated by $\sigma$-receptors, the effects of the pretreatment with the selective $\sigma$-receptor antagonist BD-1063 were determined. To assess the specificity of action for ethanol, the effects of DTG on self-administration of equally reinforcing solutions of saccharin (non-caloric) or sucrose (caloric) were also determined. Finally, gene expression of the three opioid receptors was analyzed in reward-related brain areas of ethanol-naive $\mathrm{sP}$ rats treated acutely or repeatedly with DTG and compared with that of vehicle-treated $\mathrm{sP}$ rats.

The present series of studies were performed in $\mathrm{sP}$ rats. Our line of sP rats descend from the original line that were selectively bred from a Wistar stock by Prof GL Gessa (University of Cagliari, Italy). The selectively bred sP rat (Colombo, 1997) provides a model with significant face validity for alcoholism (Colombo et al, 2006; McBride and $\mathrm{Li}, 1998)$, as the sP rat voluntarily drinks high quantities of ethanol and has a heritable component similar to human ethanol dependence (Bohman et al, 1981; Cloninger et al, 1981; Prescott and Kendler, 1999; Sigvardsson et al, 1996). $\mathrm{sP}$ rats meet most of the fundamental criteria for an animal model of alcoholism (Colombo et al, 2006), and earlier work has established predictive validity for identifying potential pharmacotherapies for alcoholism.

\section{MATERIALS AND METHODS}

\section{Animals}

Genetically selected adult male sP rats $(300-350 \mathrm{~g}$ at study onset) were subjects in this study. Rats were housed in groups of two-three per cage in a humidity- and temperature $\left(22^{\circ} \mathrm{C}\right)$-controlled vivarium on a 12 -h lightdark cycle (lights off at 10:00 am) with water and regular rodent chow available ad libitum. Experiments were conducted during the rats' dark cycle. Different sets of rats were used for each experiment. All experimental procedures adhered to the guidelines of the National 
Institutes of Health Guide for the Care and Use of Laboratory Animals and were approved by the Institutional Animal Care and Use Committee of The Scripps Research Institute and Boston University Medical Campus.

\section{Drugs}

Ethanol solution $(10 \% v / v)$ was prepared using $95 \%$ ethyl alcohol and tap water. Saccharin and sucrose solutions (0.04 and $1.5 \% w / v$, respectively) were prepared using sucrose or saccharin sodium salt hydrate (both from Sigma Aldrich) and tap water. DTG was purchased from Tocris Bioscience (Ellisville, MO); BD-1063 was synthesized as previously described by KCR (de Costa et al, 1993). DTG was suspended in isotonic saline with a few drops of Tween-20; a dose of $15 \mathrm{mg} / \mathrm{kg}$ was administered subcutaneously in a volume of $2 \mathrm{ml} / \mathrm{kg}$ of body weight twice a day (right before the dark cycle onset and at the end of the dark cycle); for the antagonist reversal study, a dose of BD-1063 without intrinsic action on ethanol self-administration $(7 \mathrm{mg} / \mathrm{kg})$ was dissolved in isotonic saline and administered subcutaneously in a volume of $1 \mathrm{ml} / \mathrm{kg}, 15 \mathrm{~min}$ before the DTG administration. The dose of BD-1063 was chosen on the basis of our previous work on sP rats (Sabino et al, 2009a, b); doses of DTG were on the basis of the literature (Matsumoto et al, 2001; Skuza and Rogoz, 2007; Ajmo et al, 2006; Rawls et al, 2002), and on preliminary observations. Both fixed ratio-1 (FR1) and progressive ratio (PR) selfadministration sessions occurred approximately $4 \mathrm{~h}$ after the last injection.

\section{Apparatus For Operant Oral Ethanol Self-Administration}

The test chambers used for operant oral self-administration (Coulbourn Instruments, Allentown, PA) were located in sound-attenuating, ventilated environmental cubicles. Syringe pumps (Razel Scientific Instruments, Stamford, CT) dispensed ethanol or water into two stainless steel drinking cups mounted $4 \mathrm{~cm}$ above the grid floor in the middle of one side panel. Two retractable levers were located $4.5 \mathrm{~cm}$ to either side of the drinking cups. Fluid delivery and recording of operant responses were controlled by microcomputers.

\section{Self-Administration Procedure: Fixed Ratio}

$\mathrm{sP}$ rats were trained to self-administer $10 \% v / v$ ethanol, as previously reported, without any fading procedure (Sabino et al, 2009a), under a continuous FR1 schedule of reinforcement, wherein each response resulted in the delivery of $0.1 \mathrm{ml}$ of fluid. Briefly, $\mathrm{sP}$ rats were first allowed continuous (24-hr/day) two-bottle choice access to ethanol $(10 \% \mathrm{w} / \mathrm{v})$ and water in their home cages for 2 weeks, and then allowed limited daily access (1-h/day) for 6 days. Rats were then allowed overnight (16h) two-choice operant access to ethanol or water with chow available ad libitum. Following this initial overnight session, all subsequent ethanol self-administration daily sessions were $60 \mathrm{~min}$ in duration. Lever presses had no scheduled consequences for $2.01 \mathrm{~s}$ after the activation of the pumps to avoid double responses, as previously reported (Sabino et al, 2006). For saccharin or sucrose self-administration, separate sets of $\mathrm{sP}$ rats were used; rats were trained to self-administer either saccharin $(0.04 \% \mathrm{w} / \mathrm{v})$ or sucrose $(1.5 \% \mathrm{w} / \mathrm{v})$ solutions under an FR1 schedule during 60-min FR1 sessions (Sabino et al, 2009a). These concentrations maintained response rates similar to those elicited by ethanol. During all sessions, rats were also allowed to press for water $(0.1 \mathrm{ml})$ on the opposite lever (FR1). Testing began when performance stabilized $(<15 \%$ variation across three consecutive sessions).

\section{Self-Administration Procedure: Progressive Ratio}

A different set of rats were trained to self-administer $10 \%$ $v / v$ ethanol under a PR schedule of reinforcement. Under this schedule, the number of responses required to produce one delivery of ethanol increased with successive deliveries based on the following exponential progression: response ratio $=4 \times\left(\mathrm{e}^{\# \text { of } \text { reinforcer }{ }^{\star} 0.1}\right)-3.8$, rounded to the nearest integer as in Sabino et al (2009a). The session was defined as starting upon completion of the first ratio, with the latency to complete the first ratio recorded as a dependent measure, and set to a maximum of $2 \mathrm{~h}$. To avoid unintended session starts, the first reinforcement required three responses. Thus, the PR schedule was $3,1,2,2,3,3,4,5$, $6,7,8,9,11,12,14,16,18,20,23$, etc. responses; sessions ended when subjects had not completed a ratio for $14 \mathrm{~min}$, as we previously reported (Sabino et al, 2009a; Walker and Koob, 2007; Gilpin et al, 2010), with the last completed ratio defined as the breakpoint. Responses on the inactive lever were also recorded. Testing began when performance stabilized ( $<15 \%$ variation across three consecutive sessions).

\section{Procedure for Blood Alcohol Levels Determination}

To determine blood alcohol levels that resulted from selfadministration, blood samples $(50 \mu \mathrm{l})$ were collected from the tip of each rat's tail, 25 min after the beginning of the FR1 self-administration session on day 8 of treatment. After centrifugation, plasma was assayed for alcohol content by injection into an oxygen-rate alcohol analyzer (Analox Instruments, Lunenburg, MA).

\section{Quantitative Real-Time PCR (qPCR)}

To determine the effect of repeated $\sigma$ receptor agonist administration on opioid-receptor gene expression in the VTA and in the nucleus accumbens (NAcc), key rewardrelevant brain regions, ethanol naive sP rats were divided into three groups matched for body weight and assigned to control, acute DTG, and chronic DTG conditions. Rats in the control and the chronic DTG groups received vehicle and DTG treatment, respectively, twice a day for 7 days; those in the acute DTG group received 13 vehicle injections per the same schedule followed by a final, single injection of DTG. Five hours after the last injection, corresponding to the time of self-administration sessions in the behavioral experiments, rats were anesthetized with isoflurane and immediately decapitated. Brains were removed and sliced $(2 \mathrm{~mm}$ slices) in a rat brain matrix; the regions of interest were then punched with a 14-gauge needle and kept frozen at $-80^{\circ} \mathrm{C}$ until processing. 
Table I qPCR Primer Sequences and Conditions of Reaction

\begin{tabular}{|c|c|c|}
\hline Target gene & Cyclophilin A & $\mu$ type opioid receptor (MOR-I) \\
\hline RGD symbol & Ppia & Oprml \\
\hline Primer A & TAT CTG CAC TGC CAA GAC TGA GTG & TGT GTA GTG GGC CTC TTC GGA AAC \\
\hline Primer B & CTT CTT GCT GGT CTT GCC ATT CC & TGA AAG GGC AGT GTA CTG GTC GC \\
\hline Temperatures $\left({ }^{\circ} \mathrm{C}\right)$ & $95-58-72$ & $95-58.6-72$ \\
\hline Times (s) & $20-15-10$ & $15-10-10$ \\
\hline RGD symbol & Oprdl & Oprkl \\
\hline Primer A & GCC AAG GCC AAG CTG ATC AAC AT & TGT GGT GTT TGT GGT GGG CTT AG \\
\hline Primer B & TGG GGA ACT GGA GCG TGC AT & AGC ACT CTG GAA GGG CAT AGT GGT \\
\hline Temperatures $\left({ }^{\circ} \mathrm{C}\right)$ & $95-58.6-72$ & $95-58.6-72$ \\
\hline
\end{tabular}

Primers and conditions used in qPCR for the detection of mRNA levels of opioid receptors and the housekeeping gene in punches obtained from the brains of ethanol-naive rats treated either acutely or repeatedly with the $\sigma$ receptor agonist DTG.

The RNA extraction, retrotranscription, and real-time PCR were performed as in Sabino et al (2009a) and Cottone et al (2009). Total RNA was prepared from each brain punch using the RNeasy mini kit (Qiagen, Valencia, CA) following the standard protocol for RNA extraction from animal tissues. One microgram of total RNA was reverse transcribed with SuperScript First-Strand Synthesis System for RT-PCR (Invitrogen, Carlsbad, CA) in the presence of Oligo (dT) 15 following the manufacturer's instructions. For quantitative real-time PCR, Roche Light Cycler 480 Master-plus SYBR Green mix (Roche Applied Science, Indianapolis, IN) was used. Reactions were carried out in a $20 \mu \mathrm{l}$ volume using a 96-well plate Realplex ${ }^{4}$ machine (Eppendorf); the primers (used at a final concentration of $0.5 \mu \mathrm{M}$ ) were synthesized by Valuegene (San Diego, CA), using a standard desalting purification method.

Fragments were amplified using a three-step RT-PCR protocol that included an initial $94{ }^{\circ} \mathrm{C}$ for $5 \mathrm{~min}$ step to activate Taq polymerase, followed by 40 cycles of amplification. The conditions of the reactions and sequences of the primers are listed in Table 1. Standard curves were constructed using purified and sequenced fragments. The results were analyzed by the second derivative methods and are expressed in arbitrary units normalized by the expression levels of the reference gene, Cyclophilin A.

The standard curve and the samples were analyzed in duplicate; qPCR reactions for each brain region were performed in different runs. Gene-specific amplification was determined by melting curve analysis as one peak at the expected melting temperature and by agarose gel electrophoresis.

\section{Statistical Analysis}

Intake data were analyzed by analysis of variance (ANOVA) and are expressed as mean \pm SEM, normalized for body weight (ie, ethanol, g/kg; water, $\mathrm{ml} / \mathrm{kg}$ ). The effects of DTG on ethanol, sucrose, and saccharin self-administration were analyzed by a two-way ANOVA, with DTG treatment as a between-subjects factor and day as a within-subjects factor.
The data resulting from the antagonist reversal experiment were analyzed using a three-way ANOVA, with agonist and antagonist treatment as between-subjects factors and day as a within-subjects factor. Data resulting from the gene expression qPCR experiment were analyzed using a one-way ANOVA with DTG treatment as a betweensubjects factor. Pairwise post-hoc comparisons were made using Student's $t$ test (to compare performance between two groups) or Dunnett's test for all other comparisons $v s$ vehicle conditions, after significant omnibus effects $(p<0.05)$.

\section{RESULTS}

\section{Repeated DTG Administration Increases Ethanol Self-Administration (Fixed Ratio 1)}

Figure 1 shows how repeated treatment (7 days) with the $\sigma$-receptor agonist DTG (15 mg/kg, twice a day) affected ethanol intake in $\mathrm{sP}$ rats under an FR1 schedule of reinforcement (DTG: $F(1,14)=12.97, p=0.003$; day $\times$ DTG: $F(6,84)=9.61, p=0.000$; day: $F(6,84)=8.87, p=0.0001)$. Post-hoc comparisons showed that DTG-treated rats consumed significantly more ethanol than vehicle-treated rats beginning from day 4 of treatment and reached a $92 \%$ increase $v s$ controls during the last self-administration session. Water intake was not significantly affected by DTG treatment (DTG: $F(1,14)=3.81$, n.s.; day $\times$ DTG: $F(6,84)=1.54$, n.s.) (Table 2).

The inset of Figure 1 shows that blood alcohol levels, measured $25 \mathrm{~min}$ after the beginning of the self-administration session on day 8 of treatment, were significantly higher in the DTG-treated group compared with controls (104\% increase: $\mathrm{mg} / \mathrm{dl}, 46.36 \pm 9.55$ vs $94.46 \pm 14.96$, vehicle vs DTG, respectively; ethanol intake after $25 \mathrm{~min}$ of session: $\mathrm{g} / \mathrm{kg}, 0.82 \pm 0.11$ vs $1.44 \pm 0.18$, vehicle $v s \mathrm{DTG}$, respectively). DTG was administered twice daily, with the morning drug treatment preceding the self-administration session by at least $4 \mathrm{~h}$, thereby reducing possible acute effects of the drug. 


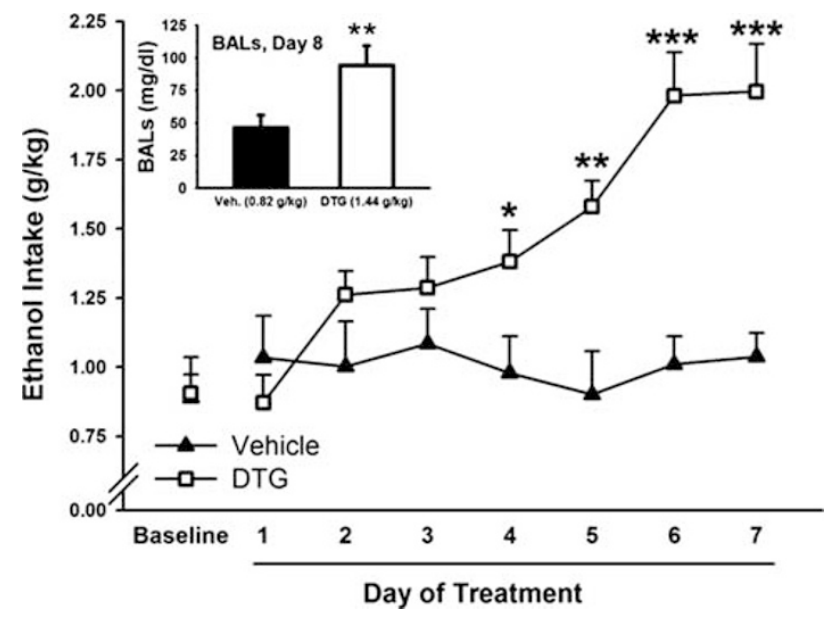

Figure I Effect of repeated subcutaneous pretreatment (twice a day for 7 days) with the $\sigma$-receptor agonist DTG on alcohol self-administration on a fixed-ratio I schedule of reinforcement in $\mathrm{SP}$ rats during 60-min sessions ( $n=8$ /group). Data represent mean \pm SEM intake normalized for body weight. The inset shows the blood alcohol levels of the two groups during day 8 of DTG administration, 25 min into the self-administration session. $* 0<0.05$, *** $p<0.0$ I, **** $p<0.00$ I vs vehicle-treated group (Student's $t$ test).

Table 2 Effects of DTG on Concurrent Water Self-Administration

\begin{tabular}{lcc}
\hline & Water $(\mathbf{m l} / \mathbf{k g})$ & \\
\hline & Vehicle & DTG \\
\hline Baseline & $0.36 \pm 0.16$ & $0.29 \pm 0.08$ \\
Day 1 & $0.38 \pm 0.10$ & $0.65 \pm 0.30$ \\
Day 2 & $0.23 \pm 0.08$ & $0.16 \pm 0.08$ \\
Day 3 & $0.38 \pm 0.11$ & $0.52 \pm 0.22$ \\
Day 4 & $0.33 \pm 0.12$ & $1.18 \pm 0.54$ \\
Day 5 & $0.28 \pm 0.06$ & $0.82 \pm 0.44$ \\
Day 6 & $0.05 \pm 0.03$ & $0.90 \pm 0.26$ \\
Day 7 & $0.12 \pm 0.09$ & $0.82 \pm 0.40$ \\
\hline
\end{tabular}

Effect of repeated subcutaneous pretreatment (twice a day for 7 days) with the $\sigma$ receptor agonist DTG on water self-administration (concurrent to ethanol) on a fixed-ratio I schedule of reinforcement in $\mathrm{SP}$ rats during 60-min sessions ( $n=8 /$ group). Data represent mean \pm SEM intake $(\mathrm{ml})$ normalized for body weight. No significant effects on water self-administration were observed.

Pretreatment with BD-1063 Prevents the DTG-Induced Increase in Ethanol Self-Administration (Fixed Ratio 1)

Pretreatment with the $\sigma$-receptor antagonist BD- $1063 * 2$ $\mathrm{HBr}$, administered at a dose that has no effect on alcohol intake per se $(4.4 \mathrm{mg} / \mathrm{kg}$, based on the free base molecular weight), completely prevented the DTG-induced increase in ethanol self-administration $(\mathrm{DTG} \times \mathrm{BD}-1063$ : $F(1,28)=$ 5.16, $p<0.05$; DTG $\times$ BD- $1063 \times$ day: $F(6,168)=1.46$, n.s. $)$. Figure 2 shows the cumulative ethanol intake of the groups during the 7 days of treatment.

\section{Repeated DTG Administration Increases the Motivation to Self-Administer Ethanol (Progressive Ratio)}

Figure 3 shows that repeated treatment with the $\sigma$-receptor agonist DTG increased the breakpoint of sP rats to work for

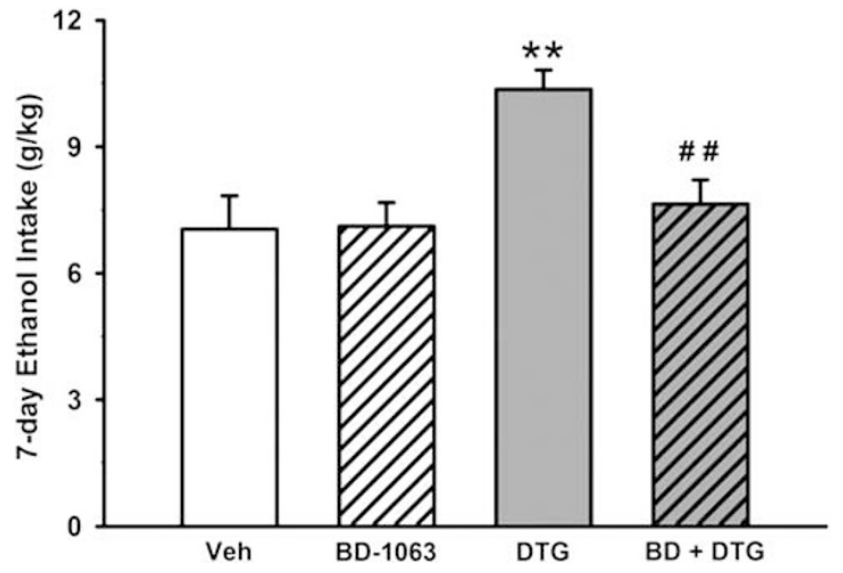

Figure 2 Effect of pretreatment with the selective $\sigma$-receptor antagonist BD-1063 (- I $5 \mathrm{~min})$ on DTG-induced increase in alcohol self-administration on a fixed-ratio I schedule of reinforcement in $\mathrm{SP}$ rats ( $n=8 /$ group). Data represent the cumulative (7 days) mean \pm SEM intake normalized for body weight. ${ }^{*} p<0.01$ vs vehicle-treated group, ${ }^{\#} p<0.01$ vs DTGtreated group (Dunnett's test).

ethanol under a PR schedule of reinforcement (DTG: $F(1,13)=8.49, p=0.012)$, as well as the total responses for ethanol (DTG: $F(1,13)=8.30, p=0.013$ ). In PR conditions, DTG increased the breakpoint and total responses for ethanol even on the first day of treatment, as reflected by a non significant statistical day $\times$ DTG interaction $(F(6,78)=1.64$, n.s.), and a significant pairwise difference between treatment groups on day 1 . The difference between groups descriptively appeared to increase across days of repeated DTG treatment, as shown in Figure 3. The number of responses on the inactive lever was not significantly affected by DTG treatment $(F(4,40)=2.57$, n.s.; number of inactive lever presses in Veh vs DTG group, respectively, baseline: $1.29 \pm 0.42$ and $1.63 \pm 0.65$, day 7: $0.50 \pm 0.38$ and $2.00 \pm 0.93$ ).

\section{Repeated DTG Administration Increases Saccharin and} Sucrose Self-Administration (Fixed Ratio 1)

Repeated treatment (7 days) with the $\sigma$-receptor agonist DTG $(15 \mathrm{mg} / \mathrm{kg}$, twice a day) increased saccharin intake $($ day $\times$ DTG: $\quad F(6,54)=180.72, \quad p=0.0001 ; \quad$ DTG: $F(1,9)=0.09$, n.s.; day: $F(6,54)=174.91, p=0.0001)$, as well as sucrose intake $($ day $\times$ DTG: $F(6,54)=4.09, p=0.002$; DTG: $\quad F(1,9)=18.01, \quad p=0.002 ; \quad$ day: $\quad F(6,54)=7.29$, $p=0.000)$ in $\mathrm{sP}$ rats under an FR1 schedule of reinforcement (Table 3). Post-hoc comparisons showed that DTGtreated rats consumed significantly more saccharin than vehicle-treated rats beginning from day 2 of treatment, and sucrose from day 4. Water intake was not significantly affected by DTG treatment (Saccharin, DTG: $F(1,9)=4.81$, n.s.; day $\times$ DTG: $\quad F(6,54)=0.51$, n.s.; Sucrose, DTG $F(1,9)=1.89$, n.s.; day $\times$ DTG: $F(6,54)=1.16$, n.s. $)$.

DTG was administered twice daily, with the morning drug treatment preceding the self-administration session by at least $4 \mathrm{~h}$, thereby reducing possible acute effects of the drug.

\section{Repeated DTG Treatment Increases $\mu$ - and $\delta$-Opioid Receptor mRNA in the Ventral Tegmental Area}

Repeated treatment with the $\sigma$-receptor agonist DTG in ethanol-naive $\mathrm{sP}$ rats induced a significant increase in the 

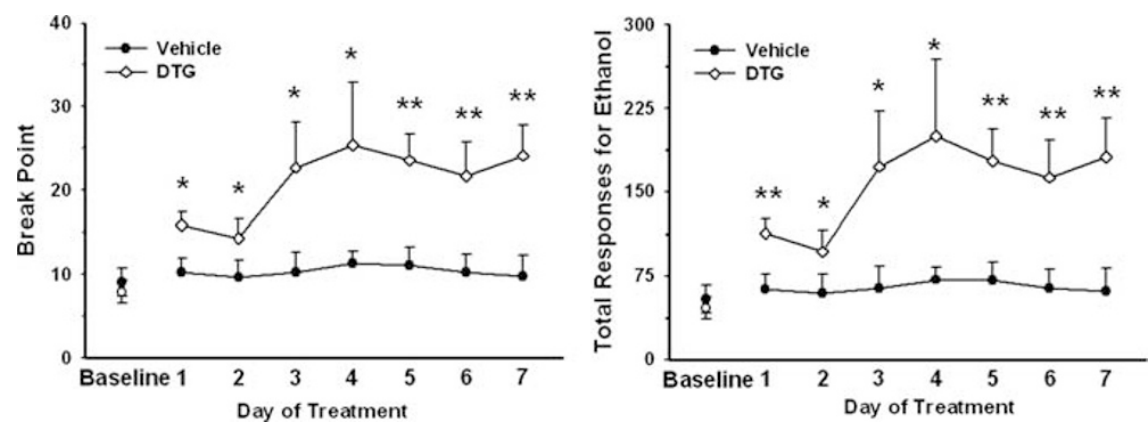

Figure 3 Effect of repeated subcutaneous pretreatment (twice a day for 7 days) with the $\sigma$-receptor agonist DTG on alcohol self-administration on breakpoint (left panel) and total responses (right panel) for alcohol in sP rats ( $n=7-8 /$ group) tested under a progressive ratio schedule of reinforcement. Data represent mean \pm SEM. $* p<0.05$, ${ }^{*} p<<0.0$ I vs vehicle-treated group (Student's $t$ test).

Table 3 Effects of DTG on Saccharin and Sucrose Self-Administration

\begin{tabular}{|c|c|c|}
\hline & Vehicle & DTG \\
\hline \multicolumn{3}{|c|}{ Saccharin (number of lever presses) } \\
\hline Baseline & $43.5 \pm 8.7$ & $45.8 \pm 10.0$ \\
\hline Day 1 & $51.6 \pm 11.0$ & $72.0 \pm 13.2$ \\
\hline Day 2 & $62.2 \pm 9.1$ & $\mid 14.5 \pm 19.1 *$ \\
\hline Day 3 & $55.6 \pm 10.5$ & $159.8 \pm 18.6 * *$ \\
\hline Day 4 & $55.8 \pm 9.4$ & $\mid 45.3 \pm 5.9$ **** \\
\hline Day 5 & $61.8 \pm 8.9$ & $154.5 \pm 12.0 * * * *$ \\
\hline Day 6 & $49.4 \pm 9.7$ & $118.7 \pm 22.0 *$ \\
\hline Day 7 & $41.6 \pm 10.6$ & $130.5 \pm 16.5$ *** \\
\hline \multicolumn{3}{|c|}{ Sucrose (number of lever presses) } \\
\hline Baseline & $54.6 \pm 12.8$ & $57.0 \pm 8.4$ \\
\hline Day 1 & $60.6 \pm 12.7$ & $72.0 \pm 9.4$ \\
\hline Day 2 & $61.2 \pm 13.7$ & $92.2 \pm 15.4$ \\
\hline Day 3 & $62.0 \pm 14.5$ & $114.0 \pm 19.6$ \\
\hline Day 4 & $65.4 \pm 13.4$ & $180.2 \pm 7.8 * * * *$ \\
\hline Day 5 & $84.0 \pm 9.2$ & $176.2 \pm 16.2 * * *$ \\
\hline Day 6 & $75.2 \pm 10.9$ & $122.3 \pm 32.2$ \\
\hline Day 7 & $76.4 \pm 13.4$ & $166.5 \pm 9.8 * * * *$ \\
\hline
\end{tabular}

Effect of repeated subcutaneous pretreatment (twice a day for 7 days) with the $\sigma$ receptor agonist DTG on saccharin $(0.04 \% \mathrm{w} / \mathrm{v}$, left $)$ or sucrose ( $1.5 \% \mathrm{~W} / \mathrm{v}$, right) self-administration on a fixed-ratio I schedule of reinforcement in $\mathrm{SP}$ rats during 60 -min sessions ( $n=5-6 /$ group). Data represent mean $\pm \mathrm{SEM}$ intake of the number of lever presses. $* p<0.05$, $* * 0<0.0$ I, $* * * * 00.00$ I vs vehicle-treated group (Student's $t$ test).

levels of mRNA for both the $\mu$ - and $\delta$-opioid receptors in the VTA, as shown in Figure $4(\mathrm{Oprm} 1: F(2,23)=3.49$, $p<0.05$; Oprd1: $F(2,22)=4.69, p<0.05)$. In contrast, $\kappa$-opioid receptor mRNA levels were not significantly altered (Oprk1: $F(2,22)=0.80$, n.s.). Post-hoc comparisons showed that the levels of the transcripts were significantly increased in rats treated repeatedly, but not acutely, with DTG, as compared with vehicle-treated rats.

Changes in the levels of mRNA for the opioid receptors were not observed in the NAcc (Oprm1: $F(2,23)=0.29$, n.s.; Oprd1: $F(2,23)=2.86$, n.s.; Oprk1: $F(2,23)=1.96$, n.s.). A trend toward a reduction in the levels of mRNA for the $\delta$-opioid receptor could be observed in the NAcc of the acutely treated rats $(p=0.077)$.

\section{DISCUSSION}

The main finding of the present study was that the $\sigma$-receptor agonist DTG, administered repeatedly to sP rats, induced binge-like drinking and increased the breakpoint to work for alcohol, indicating that the treatment potentiated the reinforcing effects of ethanol. The binge-like drinking induced by DTG was prevented by pretreatment with the selective $\sigma-1$ receptor antagonist BD-1063, indicating a $\sigma-1$ receptor mechanism of action. The $\sigma$-receptor agonist DTG, administered repeatedly to sP rats, also dramatically increased saccharin and sucrose consumption, indicating that the treatment potentiated the reinforcing effects of sweet solutions with and without calories. Our finding that the $\sigma$-receptor agonist potentiated the reinforcing efficacy of ethanol and led to binge-like ethanol intake is consistent with earlier findings that $\sigma$-receptor agonists enhance ethanol-induced CPP (Maurice et al, 2003), and that $\sigma$-receptor antagonists can reduce excessive ethanol intake and the reinforcing effects of ethanol in both genetic and environmental models of high ethanol intake (Sabino et al, 2009a, b). Repeated administration of DTG also increased the mRNA expression of $\mu$ - and $\delta$-opioid receptors in the VTA of ethanol-naive sP rats. The results collectively support an important facilitatory role for brain $\sigma-1$ receptors in excessive ethanol intake and reinforcement.

Under an FR1 schedule of reinforcement, the rats treated with DTG progressively increased their ethanol intake, reaching statistical significance beginning from day 4 of treatment. DTG-treated rats achieved an intake of $2 \mathrm{~g} / \mathrm{kg}$ of unsweetened $10 \%$ ethanol over $60 \mathrm{~min}$ by day 6 of treatment. The increased self-administration of rats treated with DTG resulted in blood alcohol levels that exceeded $80 \mathrm{mg} \%$, and can therefore be characterized as 'binge-like', according to the definition provided by the National Institute on Alcohol Abuse and Alcoholism (NIAAA, 2004), as drinking occurred within a 60-min time frame. Importantly, treatment of animals with $\sigma$-receptor agonists might represent a new method to induce binge drinking in laboratory animals, which historically has been difficult to achieve. Studies in outbred rats, with or without a history of ethanol dependence, are needed to establish the generality of the phenomenon. 

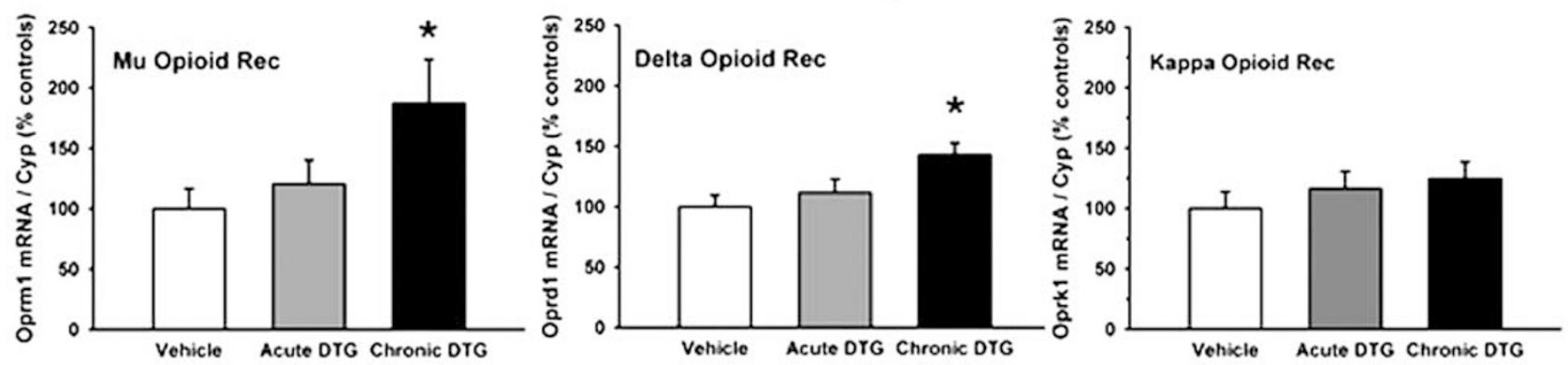

mRNA levels in Nucleus Accumbens
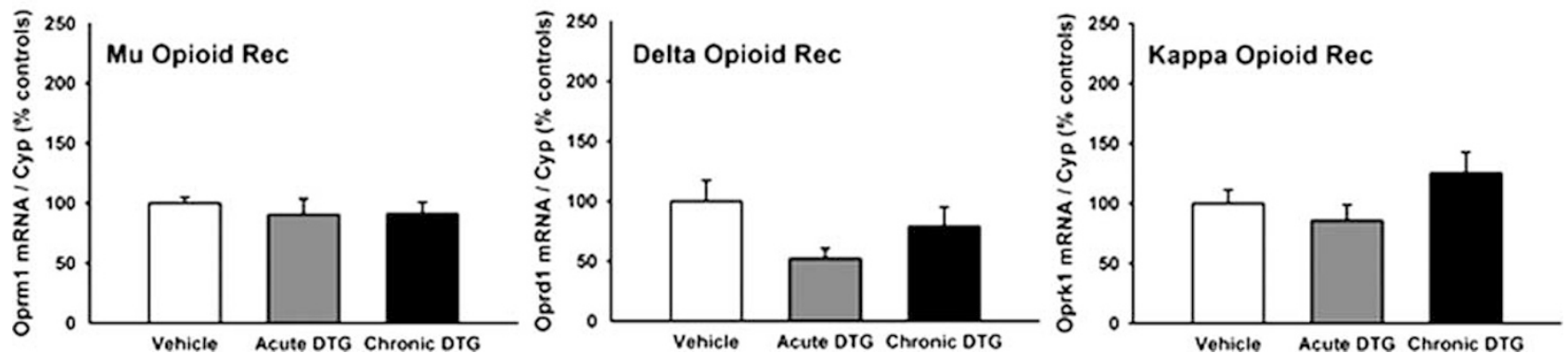

Figure $4 \mu$-, $\delta$ - and $\kappa$-opioid receptor mRNA expression in the ventral tegmental area (top panels) and in the NAcc (bottom panels) of ethanol-naive Sardinian alcohol-preferring (sP) rats treated with vehicle or acutely or chronically with DTG ( $n=8-9 /$ group). Rats were killed $4-5 \mathrm{~h}$ after the last treatment. Data represent mean \pm SEM expressed as percent of the vehicle-treated group. ${ }^{*} p<0.05$ vs vehicle-treated rats (Dunnett's test).

To our knowledge, few other drugs have been shown to increase ethanol intake in animal models, and these include morphine (at low doses; Herz, 1997) and related $\mu$-receptor agonists (Sabino et al, 2007), cannabinoid agonists such as WIN55212-2 (Colombo et al, 2002; Colombo et al, 2005) and, under some paradigms, nicotine (Lopez-Moreno et al, 2007; Lopez-Moreno et al, 2004). In addition, benzodiazepines have been shown to facilitate ethanol self-administration in rats (Deutsch and Walton, 1977), as well as low doses of gabapentin (Roberto et al, 2008).

A PR schedule of reinforcement was also used in this series of studies. Under PR reinforcement schedules, ratio requirements increase with subsequent reinforcer deliveries, and the influence of local response rates on performance are reduced. DTG dramatically increased the breakpoint, an objective measure of the effort an animal will expend to obtain a reinforcer that is sensitive both to the subjects' incentive state and to the reinforcers' stimulus properties (Walker et al, 2008). Thus, the $\sigma$-receptor agonist increased not only ethanol intake, but also the work that rats would emit to obtain ethanol, indicating that $\sigma$-receptor activation enhances the reinforcing value of alcohol. The PR results therefore clarify that the increase in FR responding following DTG indeed appear to reflect an increase in the reinforcing efficacy of ethanol, rather than decreased reinforcement as can sometimes be seen on simple FR schedules with other drugs of abuse (Caine and Koob, 1994; Maldonado et al, 1993).

Rats treated with DTG showed an increase in their breakpoint by the first day of treatment, unlike what was observed on the FR schedule. One explanation of this apparent difference is that under FR conditions, tolerance may need to develop over several sessions in order for the rats to reach such high levels of ethanol intake and tolerate the associated blood alcohol levels. In contrast, under our PR schedule of reinforcement, blood alcohol levels are substantially lower and would not limit responding (personal observations). Such a limit on blood alcohol levels may explain why a significant increase in the motivation to obtain alcohol was observed by the first day of treatment, but a significant increase in daily ethanol intake under FR conditions was not observed until 4 days of treatment.

No effect on concurrent water self-administration (FR1) and no effect on responding on the inactive lever (PR) were observed following treatment with DTG, demonstrating the specificity of $\sigma-1$ receptors agonist action on ethanol selfadministration and suggesting that there was no general non-specific stimulant-like effect. A number of previous reports showed a lack of any locomotor-enhancing effect of this and other $\sigma$ receptor agonists (Maurice et al, 2003; Romieu et al, 2000).

To determine the selectivity of action of repeated DTG administration, we tested the effects of DTG on the self-administration of solutions of either saccharin or sucrose, equally reinforcing to the $10 \%$ alcohol solutions (same number of lever presses under vehicle conditions). The significant increase in self-administration of both sucrose (caloric) and saccharin (non-caloric) suggests that DTG increases the reinforcing efficacy also of non-drug reinforcers. In contrast, we demonstrated that $\sigma$-receptor antagonists do not decrease saccharin or sucrose intake at doses effective at reducing alcohol intake. The discrepancy between the selectivity of $\sigma$-antagonists and $\sigma$-agonists may be because the dose and frequency of treatment with $\sigma$-agonists used in the present study may have overstimulated the $\sigma$-receptor system, creating a more pathological-like state characterized by a hyperfunctioning 
of the $\sigma$-receptor system. It is also worth mentioning that one of the few drugs currently approved for the treatment of alcohol-related disorders, naltrexone, reduces not only the intake of alcohol, but also that of sweet solutions, suggesting that absolute selectivity may be a characteristic very much desired for a treatment but not always indispensable.

Consistent with this hypothesis, the effects observed on the intake of sweet solutions are consistent with our proposed mechanism of action involving $\mu$ - and $\delta$-opioid receptors (see below for a more detailed discussion). Endogenous opioids have in fact been implicated in the hedonic assessment of palatability and opioid receptor agonists have been shown to increase the intake of palatable solutions and palatable food reward, effects likely mediated by the NAcc (Ruegg et al, 1997; Zhang and Kelley, 2002; Gosnell and Patel, 1993; Olszewski and Levine, 2007). Nevertheless, as DTG increased also the intake of a non-caloric solution (saccharin), our data do not support the alternative hypothesis that DTG simply increases caloric intake.

The present effects of the $\sigma$-receptor agonist DTG can be attributed to its actions at the $\sigma$-receptor. DTG is highly selective for $\sigma$-receptor over other binding sites, exhibiting at least 200-fold greater affinity for $\sigma$ receptors over $N$-methyl-D-aspartate (NMDA) and other receptors (Lever et al, 2006; Moison et al, 2003; Su, 1993). In addition, the effects of DTG were blocked by BD-1063, a selective $\sigma$-receptor antagonist (de Costa et al, 1993; Matsumoto et al, 1995). Two subtypes of $\sigma$-receptors have been identified, with the majority of studies implicating a role for the $\sigma-1$ receptor subtype in altering the effects of drugs. However, some studies have also proposed a role of the putative $\sigma-2$ receptor in modulating the dopamine system (Nuwayhid and Werling, 2006) and the effects of cocaine (Matsumoto and Mack, 2001). Although DTG is very selective for $\sigma$-receptors, it does not discriminate between the two subtypes (binding affinity [Kd] for $\sigma-2$ receptor: $21 \mathrm{nM}$; Moison et al, 2003). The antagonist reversal study, however, suggests that the effect of DTG is mediated by the $\sigma-1$ receptors, because the antagonist used - BD-1063 - is approximately 50 -fold more selective for $\sigma-1$ receptors over $\sigma-2$ receptors (Matsumoto et al, 1995; McCracken et al, 1999) and was applied at a modest systemic dose of $4.4 \mathrm{mg} / \mathrm{kg}$ free base.

Our results showing that the $\sigma$-receptor agonist potentiate the reinforcing efficacy of ethanol are broadly consistent with earlier findings that $\sigma$-receptor agonists enhance ethanol-induced CPP (Maurice et al, 2003), another procedure used to assess (albeit indirectly) the reinforcing effects of drugs. Sigma receptor agonists also potentiate cocaine self-administration. The $\sigma$ receptor agonists DTG and PRE-084 were shown to be able to shift the cocaine selfadministration dose-effect curve leftward, indicating that the activation of $\sigma$-receptors potentiates the reinforcing effects of cocaine (Hiranita et al, 2010). In addition, the $\sigma$ receptor agonists were able to maintain self-administration when substituted for cocaine, indicating the reinforcing effects of these compounds, at least in subjects trained to self-administer cocaine (Hiranita et al, 2010). However, earlier findings show that $\sigma$-receptor agonists do not produce place conditioning per se (Romieu et al, 2000; Romieu et al, 2002).

One mechanism by which the $\sigma$-receptor agonist increases the reinforcing effects of alcohol may involve the mesolimbic dopaminergic system. Selective $\sigma$-receptor ligands can potently modulate dopaminergic systems directly or indirectly through the modulation of the NMDA receptors. Sigma receptor agonists and antagonists affect dopamine synthesis, release, uptake, and metabolism in several motivation-relevant brain regions, including the striatum, NAcc, and hippocampus (Ault et al, 1998; Chaki et al, 1998; Gonzalez-Alvear and Werling, 1994; Gudelsky, 1999; Matsuno et al, 1995; Thompson et al, 2001; Weiser et al, 1995). Repeated administration of $\sigma$-receptor agonists increases the firing activity of dopaminergic neurons, including the A10 dopaminergic pathway (Ceci et al, 1988; Iyengar et al, 1990; Sanchez-Arroyos and Guitart, 1999; Zhang et al, 1993), and intravenous administration of $\sigma$-receptor agonists increases extracellular dopamine levels in the NAcc shell (Tanda et al, 2009).

Our results are also consistent with earlier findings from our laboratory showing that $\sigma$-receptor antagonists are able to selectively reduce excessive drinking in genetically selected alcohol-preferring rats, as well as in dependent outbred rats, whereas they do not affect non-dependent levels of drinking (Sabino et al, 2009a, b). On the basis of these observations and the findings presented here, it is therefore likely that endogenous $\sigma$-receptors are activated by, and may also help maintain, excessive levels of ethanol drinking.

The present findings suggest that repeated administration of $\sigma$-receptor agonists also might facilitate ethanol's ability to activate the mesolimbic dopaminergic system by upregulating expression of $\mu / \delta$-opioid receptors in the VTA. The VTA is one of the key sites for the positive reinforcing effects of ethanol (Devine and Wise, 1994; Wise and Hoffman, 1992; Rodd et al, 2004). Ethanol induces the release of $\beta$-endorphin (Herz, 1997; Jarjour et al, 2009), which is hypothesized to act on opioid receptors present on inhibitory GABA neurons in the VTA, leading to their inhibition. The resulting disinhibition of the dopaminergic projection from the VTA to the NAcc facilitates terminal dopamine release (Herz, 1997). $\beta$-endorphin has similar affinity for $\mu$ - and $\delta$-opioid receptors (Mansour et al, 1995), and it has been shown that $\beta$-endorphin-induced place preference and $\beta$-endorphin-induced dopamine release in the NAcc each involve both $\mu$ - and $\delta$-receptors (Bals-Kubik et al, 1990; Spanagel et al, 1990b). In this context, it is noteworthy that repeated DTG increased the transcription of both $\mu$ - and $\delta$-opioid receptors in the VTA of ethanolnaive rats. We hypothesize that the action of DTG on ethanol may be mediated by the $\sigma$-receptor agonist-induced upregulation of opioid receptors in the VTA, which would lead to an increased inhibition of inhibitory GABA neurons in the VTA and thereby disinhibition of mesolimbic VTANAcc dopaminergic pathway. Note that such an increase in mesolimbic dopamine activity through a $\sigma$-receptor/opioid interaction may be more 'modulated' than that observed with administration of a psychostimulant drug as there is no evidence of a psychostimulant-like effect with DTG.

The increase in opioid receptor expression in the VTA would hence be responsible for the excessive alcohol intake seen after administration of DTG; this hypothesis is consistent with several additional earlier observations. First, downregulation of the $\mu$-opioid receptor by RNA interference in the VTA reduces ethanol consumption (Lasek et al, 2007). Second, the $\delta$-opioid agonist DPDPE is self-infused into the VTA (McBride et al, 1999), Third, 
intracerebroventricular administration of DPDPE dosedependently induces an increase in the release of dopamine in the NAcc (Di Chiara and Imperato, 1988a,b; Spanagel et al, 1990a, b). Finally, systemic administration of selective $\mu$ - and $\delta$-opioid receptor antagonists, as well as the novel $\delta$-opioid receptor antagonist SoRI-9409 has been recently shown to decrease heavy-drinking in rats (Krishnan-Sarin et al, 1995; Le et al, 1993; Nielsen et al, 2008). On the basis of this literature, the upregulation of $\mu$ - and $\delta$-opioid receptors in the VTA by DTG could contribute to the ability of the $\sigma$-receptor agonist to induce binge-like drinking. Importantly, we hypothesize that hyperactivity of the endogenous $\sigma$-receptor system gives rise to excessive rates of ethanol self-administration, and therefore the effects we saw in the VTA may reflect the type of plasticity seen with chronic activation of the $\sigma$-receptors. However, a recent report describing the protective effects of $\delta$-opioid receptor expression in the VTA against excessive alcohol intake seems to contradict this hypothesis (Margolis et al, 2008).

As the experiment was carried out in ethanol-naive rats, the increase in the expression of $\mu$ - and $\delta$-opioid receptors following chronic DTG administration cannot be a consequence of the increased alcohol self-administration. It is also worth mentioning that, like every selective $\sigma$-ligand, DTG does not compete for any of the opioid receptors and, therefore, the gene expression change observed cannot be a result of a direct effect of the drug on the opioid receptor system. However, it cannot be excluded that a cross-talk between the two systems is occurring. In fact, in a recent study, Pasternak and collaborators showed that the $\sigma$-receptor can physically interact with the $\mu$-opioid receptor (co-immunoprecipitation) (Kim et al, 2010).

In summary, our finding that pharmacological activation of $\sigma$-receptors enhances the reinforcing effects of alcohol and can induce binge-like drinking, coupled with our earlier findings that $\sigma$-receptor antagonist can reduce ethanol reinforcement and excessive drinking (Sabino et al, $2009 \mathrm{a}, \mathrm{b})$, supports the hypothesis that the $\sigma$-receptor system has a key role in the reinforcing properties of alcohol. The results showing that pharmacological activation of $\sigma$-receptors can also enhance the reinforcing effects of non-caloric and caloric sweet solutions suggest a more general motivational action of the $\sigma$-system. The results thus implicate $\sigma$-receptor activation in excessive drinking and possibly binge-like behavior in general.

\section{ACKNOWLEDGEMENTS}

We thank Jeanette Helfers, Stephanie Dela Cruz, Bob Lintz and Molly Brennan for excellent technical assistance and Mike Arends and Jina Kwak for editorial assistance. This publication was made possible by grant numbers AA016731, AA006420, and AA12602 from the National Institute on Alcohol Abuse and Alcoholism, by the Peter McManus Trust, and the Pearson Center for Alcoholism and Addiction Research. The research of the Drug Design and Synthesis Section, Chemical Biology Research Branch, National Institute on Drug Abuse (NIDA), and National Institute on Alcohol Abuse and Alcoholism (NIAAA), was supported by the NIH Intramural Research Programs of the NIDA and NIAAA. The contents of this publication are solely the responsibility of the authors and do not necessarily represent the official views of the National Institutes of Health. This is manuscript number 20891 from The Scripps Research Institute.

\section{DISCLOSURE}

The authors declare no conflict of interest.

\section{REFERENCES}

Ajmo Jr CT, Vernon DO, Collier L, Pennypacker KR, Cuevas J (2006). Sigma receptor activation reduces infarct size at $24 \mathrm{~h}$ after permanent middle cerebral artery occlusion in rats. Curr Neurovasc Res 3: 89-98.

Alonso G, Phan V, Guillemain I, Saunier M, Legrand A, Anoal M et al (2000). Immunocytochemical localization of the sigma (1) receptor in the adult rat central nervous system. Neuroscience 97: 155-170.

Ault DT, Radeff JM, Werling LL (1998). Modulation of [3H] Dopamine release from rat nucleus accumbens by neuropeptide Y may involve a sigma1-like receptor. J Pharmacol Exp Ther 284: $553-560$.

Ault DT, Werling LL (1999). Phencyclidine and dizocilpine modulate dopamine release from rat nucleus accumbens via sigma receptors. Eur J Pharmacol 386: 145-153.

Aydar E, Palmer CP, Klyachko VA, Jackson MB (2002). The sigma receptor as a ligand-regulated auxiliary potassium channel subunit. Neuron 34: 399-410.

Bals-Kubik R, Shippenberg TS, Herz A (1990). Involvement of central $\mathrm{mu}$ and delta opioid receptors in mediating the reinforcing effects of beta-endorphin in the rat. Eur J Pharmacol 175: 63-69.

Bohman M, Sigvardsson S, Cloninger CR (1981). Maternal inheritance of alcohol abuse. Cross-fostering analysis of adopted women. Arch Gen Psychiatry 38: 965-969.

Bouchard P, Quirion R (1997). [3H]1,3-di(2-tolyl)guanidine and $[3 \mathrm{H}](+)$ pentazocine binding sites in the rat brain: autoradiographic visualization of the putative sigmal and sigma2 receptor subtypes. Neuroscience 76: 467-477.

Caine SB, Koob GF (1994). Effects of dopamine D-1 and D-2 antagonists on cocaine self-administration under different schedules of reinforcement in the rat. J Pharmacol Exp Ther 270: 209-218.

Ceci A, Smith M, French ED (1988). Activation of the A10 mesolimbic system by the sigma-receptor agonist (+)SKF 10047 can be blocked by rimcazole, a novel putative antipsychotic. Eur J Pharmacol 154: 53-57.

Chaki S, Okuyama S, Ogawa S, Tomisawa K (1998). Regulation of NMDA-induced [3H]dopamine release from rat hippocampal slices through sigma-1 binding sites. Neurochem Int 33: 29-34.

Cloninger CR, Bohman M, Sigvardsson S (1981). Inheritance of alcohol abuse. Cross-fostering analysis of adopted men. Arch Gen Psychiatry 38: 861-868.

Colombo G (1997). ESBRA-Nordmann 1996 Award Lecture: ethanol drinking behaviour in Sardinian alcohol-preferring rats. Alcohol Alcohol 32: 443-453.

Colombo G, Lobina C, Carai MA, Gessa GL (2006). Phenotypic characterization of genetically selected Sardinian alcohol-preferring (sP) and -non-preferring (sNP) rats. Addict Biol 11: 324-338.

Colombo G, Serra S, Brunetti G, Gomez R, Melis S, Vacca G et al (2002). Stimulation of voluntary ethanol intake by cannabinoid receptor agonists in ethanol-preferring sP rats. Psychopharmacology (Berl) 159: 181-187.

Colombo G, Serra S, Vacca G, Carai MA, Gessa GL (2005). Endocannabinoid system and alcohol addiction: pharmacological studies. Pharmacol Biochem Behav 81: 369-380. 
Cottone P, Sabino V, Roberto M, Bajo M, Pockros L, Frihauf JB et al (2009). CRF system recruitment mediates dark side of compulsive eating. Proc Natl Acad Sci USA 106: 20016-20020.

de Costa BR, He XS, Linders JT, Dominguez C, Gu ZQ, Williams W et al (1993). Synthesis and evaluation of conformationally restricted N-[2-(3,4-dichlorophenyl)ethyl]-N-methyl-2-(1-pyrrolidinyl)ethylamines at sigma receptors 2 . Piperazines, bicyclic amines, bridged bicyclic amines, and miscellaneous compounds. J Med Chem 36: 2311-2320.

Deutsch JA, Walton NY (1977). Diazepam maintenance of alcohol preference during alcohol withdrawal. Science 198: 307-309.

Devine DP, Wise RA (1994). Self-administration of morphine, DAMGO, and DPDPE into the ventral tegmental area of rats. J Neurosci 14: 1978-1984.

Di Chiara G, Imperato A (1988a). Drugs abused by humans preferentially increase synaptic dopamine concentrations in the mesolimbic system of freely moving rats. Proc Natl Acad Sci USA 85: 5274-5278.

Di Chiara G, Imperato A (1988b). Opposite effects of mu and kappa opiate agonists on dopamine release in the nucleus accumbens and in the dorsal caudate of freely moving rats. J Pharmacol Exp Ther 244: 1067-1080.

Fontanilla D, Johannessen M, Hajipour AR, Cozzi NV, Jackson MB, Ruoho AE (2009). The hallucinogen N,N-dimethyltryptamine (DMT) is an endogenous sigma-1 receptor regulator. Science 323: 934-937.

Gilpin NW, Koob GF (2010). Effects of $\beta$-adrenoceptor antagonists on alcohol drinking by alcohol-dependent rats. Psychopharmacology (Berl) 212: 431-439.

Gonzalez-Alvear GM, Werling LL (1994). Regulation of [3H]dopamine release from rat striatal slices by sigma receptor ligands. J Pharmacol Exp Ther 271: 212-219.

Gosnell BA, Patel CK (1993). Centrally administered mu- and delta-opioid agonists increase operant responding for saccharin. Pharmacol Biochem Behav 45: 979-982.

Gronier B, Debonnel G (1999). Involvement of sigma receptors in the modulation of the glutamatergic/NMDA neurotransmission in the dopaminergic systems. Eur J Pharmacol 368: 183-196.

Gudelsky GA (1999). Biphasic effect of sigma receptor ligands on the extracellular concentration of dopamine in the striatum of the rat. J Neural Transm 106: 849-856.

Gundlach AL, Largent BL, Snyder SH (1986). Autoradiographic localization of sigma receptor binding sites in guinea pig and rat central nervous system with (+)3H-3-(3-hydroxyphenyl)-N-(1propyl)piperidine. J Neurosci 6: 1757-1770.

Hanner M, Moebius FF, Flandorfer A, Knaus HG, Striessnig J, Kempner E et al (1996). Purification, molecular cloning, and expression of the mammalian sigmal-binding site. Proc Natl Acad Sci USA 93: 8072-8077.

Hayashi T, Su TP (2003). Intracellular dynamics of sigma-1 receptors (sigma(1) binding sites) in NG108-15 cells. J Pharmacol Exp Ther 306: 726-733.

Hayashi T, Su TP (2007). Sigma-1 receptor chaperones at the ERmitochondrion interface regulate $\mathrm{Ca}(2+)$ signaling and cell survival. Cell 131: 596-610.

Hayashi T, Su TP (2008). An update on the development of drugs for neuropsychiatric disorders: focusing on the sigmal receptor ligand. Expert Opin Ther Targets 12: 45-58.

Hellewell SB, Bowen WD (1990). A sigma-like binding site in rat pheochromocytoma (PC12) cells: decreased affinity for (+)benzomorphans and lower molecular weight suggest a different sigma receptor form from that of guinea pig brain. Brain Res 527: 244-253.

Herrera Y, Katnik C, Rodriguez JD, Hall AA, Willing A, Pennypacker $\mathrm{KR}$ et al (2008). sigma-1 receptor modulation of acid-sensing ion channel a (ASIC1a) and ASICla-induced Ca2+ influx in rat cortical neurons. J Pharmacol Exp Ther 327: 491-502.
Herz A (1997). Endogenous opioid systems and alcohol addiction. Psychopharmacology (Berl) 129: 99-111.

Hiranita T, Soto PL, Tanda G, Katz JL (2010). Reinforcing effects of sigma-receptor agonists in rats trained to self-administer cocaine. J Pharmacol Exp Ther 332: 515-524.

Hiranita T, Tanda G, Kopajtic TA, Newman AH, Katz JL (2009). Reinforcing effects of sigma-receptor agonists in cocaineexperienced and naive rats. Program No 496.1: Neuroscience Meeting Planner Society for Neuroscience, Chicago, IL.

Iyengar S, Dilworth VM, Mick SJ, Contreras PC, Monahan JB, Rao TS et al (1990). Sigma receptors modulate both A9 and A10 dopaminergic neurons in the rat brain: functional interaction with NMDA receptors. Brain Res 524: 322-326.

Jarjour S, Bai L, Gianoulakis C (2009). Effect of acute ethanol administration on the release of opioid peptides from the midbrain including the ventral tegmental area. Alcohol Clin Exp Res 33: 1033-1043.

Kim FJ, Kovalyshyn I, Burgman M, Neilan C, Chien CC, Pasternak GW (2010). Sigmal receptor modulation of Gprotein-coupled receptor signaling: potentiation of opioid transduction independent from receptor binding. Mol Pharmacol 77: 695-703.

Krishnan-Sarin S, Jing SL, Kurtz DL, Zweifel M, Portoghese PS, Li TK et al (1995). The delta opioid receptor antagonist naltrindole attenuates both alcohol and saccharin intake in rats selectively bred for alcohol preference. Psychopharmacology (Berl) 120: 177-185.

Lasek AW, Janak PH, He L, Whistler JL, Heberlein U (2007). Downregulation of mu opioid receptor by RNA interference in the ventral tegmental area reduces ethanol consumption in mice. Genes Brain Behav 6: 728-735.

Le AD, Poulos CX, Quan B, Chow S (1993). The effects of selective blockade of delta and $\mathrm{mu}$ opiate receptors on ethanol consumption by $\mathrm{C} 57 \mathrm{BL} / 6$ mice in a restricted access paradigm. Brain Res 630: 330-332.

Lever JR, Gustafson JL, Xu R, Allmon RL, Lever SZ (2006). Sigma1 and sigma2 receptor binding affinity and selectivity of SA4503 and fluoroethyl SA4503. Synapse 59: 350-358.

Lopez-Moreno JA, Gonzalez-Cuevas G, Navarro M (2007). The CB1 cannabinoid receptor antagonist rimonabant chronically prevents the nicotine-induced relapse to alcohol. Neurobiol Dis 25: 274-283.

Lopez-Moreno JA, Gonzalez-Cuevas G, Rodriguez de Fonseca F, Navarro M (2004). Long-lasting increase of alcohol relapse by the cannabinoid receptor agonist WIN 55 212-2 during alcohol deprivation. J Neurosci 24: 8245-8252.

Maldonado R, Robledo P, Chover AJ, Caine SB, Koob GF (1993). D1 dopamine receptors in the nucleus accumbens modulate cocaine self-administration in the rat. Pharmacol Biochem Behav 45: 239-242.

Mansour A, Fox CA, Akil H, Watson SJ (1995). Opioid-receptor mRNA expression in the rat CNS: anatomical and functional implications. Trends Neurosci 18: 22-29.

Margolis EB, Fields HL, Hjelmstad GO, Mitchell JM (2008). Deltaopioid receptor expression in the ventral tegmental area protects against elevated alcohol consumption. J Neurosci 28: 12672-12681.

Martin-Fardon R, Maurice T, Aujla H, Bowen WD, Weiss F (2007). Differential effects of sigmal receptor blockade on self-administration and conditioned reinstatement motivated by cocaine vs natural reward. Neuropsychopharmacology 32: 1967-1973.

Martin WR, Eades CG, Thompson JA, Huppler RE, Gilbert PE (1976). The effects of morphine- and nalorphine- like drugs in the nondependent and morphine-dependent chronic spinal dog. J Pharmacol Exp Ther 197: 517-532.

Matsumoto RR, Bowen WD, Tom MA, Vo VN, Truong DD, De Costa BR (1995). Characterization of two novel sigma receptor ligands: antidystonic effects in rats suggest sigma receptor antagonism. Eur J Pharmacol 280: 301-310. 
Matsumoto RR, Liu Y, Lerner M, Howard EW, Brackett DJ (2003). Sigma receptors: potential medications development target for anti-cocaine agents. Eur J Pharmacol 469: 1-12.

Matsumoto RR, Mack AL (2001). (+/-)-SM 21 attenuates the convulsive and locomotor stimulatory effects of cocaine in mice. Eur J Pharmacol 417: R1-R2.

Matsumoto RR, McCracken KA, Friedman MJ, Pouw B, De Costa BR, Bowen WD (2001). Conformationally restricted analogs of BD1008 and an antisense oligodeoxynucleotide targeting sigma1 receptors produce anti-cocaine effects in mice. Eur J Pharmacol 419: $163-174$

Matsuno K, Matsunaga KH, Mita S (1995). Acute effects of sigma ligands on the extracellular DOPAC level in rat frontal cortex and striatum. Neurochem Res 20: 233-238.

Maurice T, Casalino M, Lacroix M, Romieu P (2003). Involvement of the sigmal receptor in the motivational effects of ethanol in mice. Pharmacol Biochem Behav 74: 869-876.

Maurice T, Martin-Fardon R, Romieu P, Matsumoto RR (2002). Sigma(1) (sigma(1)) receptor antagonists represent a new strategy against cocaine addiction and toxicity. Neurosci Biobehav Rev 26: 499-527.

Maurice T, Phan VL, Urani A, Kamei H, Noda Y, Nabeshima T (1999). Neuroactive neurosteroids as endogenous effectors for the sigmal (sigma1) receptor: pharmacological evidence and therapeutic opportunities. Jpn J Pharmacol 81: 125-155.

Maurice T, Romieu P (2004). Involvement of the sigmal receptor in the appetitive effects of cocaine. Pharmacopsychiatry 37(Suppl 3): S198-S207.

McBride WJ, Li TK (1998). Animal models of alcoholism: neurobiology of high alcohol-drinking behavior in rodents. Crit Rev Neurobiol 12: 339-369.

McBride WJ, Murphy JM, Ikemoto S (1999). Localization of brain reinforcement mechanisms: intracranial self-administration and intracranial place-conditioning studies. Behav Brain Res 101: 129-152.

McCracken KA, Bowen WD, Matsumoto RR (1999). Novel sigma receptor ligands attenuate the locomotor stimulatory effects of cocaine. Eur J Pharmacol 365: 35-38.

Moebius FF, Burrows GG, Hanner M, Schmid E, Striessnig J, Glossmann H (1993). Identification of a $27-\mathrm{kDa}$ high affinity phenylalkylamine-binding polypeptide as the sigmal binding site by photoaffinity labeling and ligand-directed antibodies. Mol Pharmacol 44: 966-971.

Moison D, De Deurwaerdere P, Cagnotto A, Marrazzo A, Prezzavento O, Ronsisvalle $\mathrm{G}$ et al (2003). Intrastriatal administration of sigma ligands inhibits basal dopamine release in vivo. Neuropharmacology 45: 945-953.

Nguyen EC, McCracken KA, Liu Y, Pouw B, Matsumoto RR (2005). Involvement of sigma (sigma) receptors in the acute actions of methamphetamine: receptor binding and behavioral studies. Neuropharmacology 49: 638-645.

NIAAA (2004). NIAAA council approves definition of binge drinking. NIAAA Newsletter 3: 3.

Nielsen CK, Simms JA, Pierson HB, Li R, Saini SK, Ananthan S et al (2008). A novel delta opioid receptor antagonist, SoRI-9409, produces a selective and long-lasting decrease in ethanol consumption in heavy-drinking rats. Biol Psychiatry 64: 974-981.

Nuwayhid SJ, Werling LL (2006). Sigma(2) (sigma(2)) receptors as a target for cocaine action in the rat striatum. Eur J Pharmacol 535: 98-103.

Olszewski PK, Levine AS (2007). Central opioids and consumption of sweet tastants: when reward outweighs homeostasis. Physiol Behav 91: 506-512.

Prescott CA, Kendler KS (1999). Genetic and environmental contributions to alcohol abuse and dependence in a population-based sample of male twins. Am J Psychiatry 156: $34-40$.
Quirion R, Bowen WD, Itzhak Y, Junien JL, Musacchio JM, Rothman RB et al (1992). A proposal for the classification of sigma binding sites. Trends Pharmacol Sci 13: 85-86.

Rawls SM, Baron DA, Geller EB, Adler MW (2002). Sigma sites mediate DTG-evoked hypothermia in rats. Pharmacol Biochem Behav 73: 779-786.

Roberto M, Gilpin NW, O’Dell LE, Cruz MT, Morse AC, Siggins GR et al (2008). Cellular and behavioral interactions of gabapentin with alcohol dependence. $J$ Neurosci 28: 5762-5771.

Rodd ZA, Melendez RI, Bell RL, Kuc KA, Zhang Y, Murphy JM et al (2004). Intracranial self-administration of ethanol within the ventral tegmental area of male Wistar rats: evidence for involvement of dopamine neurons. J Neurosci 24: 1050-1057.

Romieu P, Martin-Fardon R, Maurice T (2000). Involvement of the sigmal receptor in the cocaine-induced conditioned place preference. Neuroreport 11: 2885-2888.

Romieu P, Meunier J, Garcia D, Zozime N, Martin-Fardon R, Bowen WD et al (2004). The sigmal (sigma1) receptor activation is a key step for the reactivation of cocaine conditioned place preference by drug priming. Psychopharmacology (Berl) 175: 154-162.

Romieu P, Phan VL, Martin-Fardon R, Maurice T (2002). Involvement of the sigma(1) receptor in cocaine-induced conditioned place preference: possible dependence on dopamine uptake blockade. Neuropsychopharmacology 26: 444-455.

Ruegg H, Yu WZ, Bodnar RJ (1997). Opioid-receptor subtype agonist-induced enhancements of sucrose intake are dependent upon sucrose concentration. Physiol Behav 62: 121-128.

Sabino V, Cottone P, Koob GF, Steardo L, Lee MJ, Rice KC et al (2006). Dissociation between opioid and CRF1 antagonist sensitive drinking in Sardinian alcohol-preferring rats. Psychopharmacology (Berl) 189: 175-186.

Sabino V, Cottone P, Steardo L, Schmidhammer H, Zorrilla EP (2007). 14-Methoxymetopon, a highly potent mu opioid agonist, biphasically affects ethanol intake in Sardinian alcohol-preferring rats. Psychopharmacology (Berl) 192: 537-546.

Sabino V, Cottone P, Zhao Y, Iyer MR, Steardo Jr L., Steardo L et al (2009a). The sigma-receptor antagonist BD-1063 decreases ethanol intake and reinforcement in animal models of excessive drinking. Neuropsychopharmacology 34: 1482-1493.

Sabino V, Cottone P, Zhao Y, Steardo L, Koob GF, Zorrilla EP (2009b). Selective reduction of alcohol drinking in Sardinian alcohol-preferring rats by a sigma-1 receptor antagonist. Psychopharmacology (Berl) 205: 327-335.

Sanchez-Arroyos R, Guitart X (1999). Electrophysiological effects of E-5842, a sigmal receptor ligand and potential atypical antipsychotic, on A9 and A10 dopamine neurons. Eur J Pharmacol 378: 31-37.

Sigvardsson S, Bohman M, Cloninger CR (1996). Replication of the Stockholm Adoption Study of alcoholism. Confirmatory crossfostering analysis. Arch Gen Psychiatry 53: 681-687.

Skuza G, Kolasiewicz W (2001). Repeated treatment with SA4503, a selective sigma1 receptor agonist, up-regulates alpha-adrenergic system. a behavioral study. Pol J Pharmacol 53: 547-550.

Skuza G, Rogóz Z (2007). Antidepressant-like effect of combined treatment with selective sigma receptor agonists and a 5-HT1A receptor agonist in the forced swimming test in rats. Pharmacol Rep 59: 773-777.

Spanagel R, Herz A, Shippenberg TS (1990a). The effects of opioid peptides on dopamine release in the nucleus accumbens: an in vivo microdialysis study. J Neurochem 55: 1734-1740.

Spanagel R, Herz A, Shippenberg TS (1990b). Identification of the opioid receptor types mediating beta-endorphin-induced alterations in dopamine release in the nucleus accumbens. Eur $J$ Pharmacol 190: 177-184.

Su TP (1993). Delineating biochemical and functional properties of sigma receptors: emerging concepts. Crit Rev Neurobiol 7: 187-203. 
Su TP, Hayashi T (2003). Understanding the molecular mechanism of sigma-1 receptors: towards a hypothesis that sigma-1 receptors are intracellular amplifiers for signal transduction. Curr Med Chem 10: 2073-2080.

Takahashi S, Miwa T, Horikomi K (2000). Involvement of sigmal receptors in methamphetamine-induced behavioral sensitization in rats. Neurosci Lett 289: 21-24.

Tanda G, Garces-Ramirez L, Green JL, Hiranita T, Katz JL (2009). Neurochemical effects of sigma receptor agonists: A dopaminemicrodialysis study in rats. Program No 496.4: Neuroscience Meeting Planner Society for Neuroscience, Chicago, IL.

Thompson TL, Bridges S, Miller C (2001). Modulation of dopamine uptake in rat nucleus accumbens: effect of specific dopamine receptor antagonists and sigma ligands. Neurosci Lett 312: $169-172$.

Ukai M, Mori E, Kameyama T (1997). Modulatory effects of morphine, U-50488H and 1,3-di-(2-tolyl)guanidine on cocainelike discriminative stimulus in the rat using two-choice discretetrial avoidance paradigm. Methods Find Exp Clin Pharmacol 19: 541-546.

Walker BM, Koob GF (2007). The $\gamma$-aminobutyric acid-B receptor agonist baclofen attenuates responding for ethanol in ethanoldependent rats. Alcohol Clin Exp Res 31: 11-18.
Walker BM, Rasmussen DD, Raskind MA, Koob GF (2008). alpha1noradrenergic receptor antagonism blocks dependence-induced increases in responding for ethanol. Alcohol 42: 91-97.

Walker JM, Bowen WD, Walker FO, Matsumoto RR, De CB, Rice KC (1990). Sigma receptors: biology and function. Pharmacol Rev 42: 355-402.

Weatherspoon JK, Gonzalez-Alvear GM, Frank AR, Werling LL (1996). Regulation of [3H] dopamine release from mesolimbic and mesocortical areas of guinea pig brain by sigma receptors. Schizophr Res 21: 51-62.

Weiser SD, Patrick SL, Mascarella SW, Downing-Park J, Bai X, Carroll FI et al (1995). Stimulation of rat striatal tyrosine hydroxylase activity following intranigral administration of sigma receptor ligands. Eur J Pharmacol 275: 1-7.

Wise RA, Hoffman DC (1992). Localization of drug reward mechanisms by intracranial injections. Synapse 10: 247-263.

Zhang J, Chiodo LA, Wettstein JG, Junien JL, Freeman AS (1993). Repeated administration of Sigma ligands alters the population activity of rat midbrain dopaminergic neurons. Synapse 13: 223-230.

Zhang M, Kelley AE (2002). Intake of saccharin, salt, and ethanol solutions is increased by infusion of a mu opioid agonist into the nucleus accumbens. Psychopharmacology (Berl) 159: 415-423. 